discussion of barriers above (albeit brief) is a positive step in this direction for qualitative research in the field of I-O.

\title{
References
}

Bell, S. T., Fisher, D. M., Brown, S. G., \& Mann, K. E. (in press). An approach for conducting actionable research with extreme teams. Journal of Management. Advance online publication. doi:10.1177/0149206316653805

Eby, L. T., Hurst, C. S., \& Butts, M. M. (2009). Qualitative research: The redheaded stepchild in organizational and social science research? In C. E. Lance \& R. J. Vandenberg (Eds.), Statistical and methodological myths and urban legends: Doctrine, verity and fable in the organizational and social sciences (pp. 219-246). New York, NY: Routledge.

Johns, G. (2006). The essential impact of context on organizational behavior. Academy of Management Review, 31, 386-408. doi:10.5465/AMR.2006.20208687

Kahneman, D., \& Tversky, A. (1996). On the reality of cognitive illusions. Psychological Review, 103, 582-591. doi:10.1037/0033-295X.103.3.582

Miller, G. A. (1994). The magical number seven, plus or minus two: Some limits on our capacity for processing information. Psychological Review, 101, 343-352. doi:10.1037/0033-295X.101.2.343 (Reprinted from Psychological Review, 1956, 63, 81-97)

Pratt, M. G., \& Bonaccio, S. (2016). Qualitative research in I-O psychology: Maps, myths, and moving forward. Industrial and Organizational Psychology: Perspectives on Science and Practice, 9(4), 693-715.

\section{Understanding Deep, Socially Embedded Human Motivations and Aspirations for Work From Whole Person and Interdisciplinary Perspectives}

\author{
Teresa J. Rothausen \\ University of St. Thomas-Minnesota
}

As someone trained exclusively as a quantitative researcher, who recently became a semi-autodidactic qualitative researcher (see Rothausen, Henderson, Arnold, \& Malshe, in press; "semi" in part because I am still learning and in part because my coauthors have taught me), I would like to extend the argument made by Pratt and Bonaccio (2016) for increasing qualitative research in the domains of industrial-organizational psychology (IOP), organizational behavior (OB), and human resources (HR), and I would also add industrial relations (IR), which was my doctoral field of study and "where workers went" within business and management studies as HR became more aligned with organizational interests (see Lefkowitz, 2016, from this journal). I extend their argument by deepening one of their reasons,

Teresa J. Rothausen, Department of Management, Opus College of Business, University of St. Thomas-Minnesota.

Correspondence concerning this article should be addressed to Teresa J. Rothausen, Department of Management, Opus College of Business, University of St. Thomas-Minnesota, 1000 LaSalle Avenue-TMH 443, Minneapolis, MN 55403. E-mail: tjrothausen@stthomas.edu 
understanding the "why" of work, and adding another potential use, understanding the "what could be" of work.

Growing dissatisfaction with the limits of quantitative methods and frustration with what appears to be increasing fascination with quantitative esoterica in the literatures led me to learning qualitative methods as part of a larger quest for methods to better understand employees, managers, and leaders in organizations as whole people. As the authors of the focal article point out, quantitative methods explore "Big B"-behavior as if it were context free and, I would add, as if it were primarily transactional-an exchange of work for rewards. Yet from my personal and field experience, I learned that often the meaning of work is much more nuanced and that motivation in organizations is embedded in social networks in and outside organizations, along the lines of the following: Given the constraints set up for me by my organization, and given what work means to me in my larger life, this is my behavior.

I would add also that quantitative methods reduce people to parts, such as scores on IQ or personality tests, and variables, such as the number of children they have, and thus miss patterns of the whole as well as context (see Weiss \& Rupp, 2011, from this journal). This tends to frame motivation as independent and individual. Qualitative methods allow a more comprehensive understanding of motivation for behavior related to work by allowing informants to tell their whole stories unencumbered by what researchers expect to find or what is in the literature (Creswell, 2007). This tends to make visible the constraints on behavior set by the social milieu in which workers are embedded, including those set by organizations. Individuals are never wholly independent but are interdependent with others and the larger world (Rothausen, 2016).

An example is the phenomenon of women leaving the workforce during prime productive and creative years. This was framed by some researchers and journalists as a choice and was given catchy titles such as "opting out" and "off-ramping" that also imply agency over coercion (Gregory \& Miller, 2009). But this "choice" was clearly constrained for many to organizationally determined options of working 50-60 hours per week or none at all. When the occasional employee is "allowed" to work "part-time" (often up to 40 hours per week), this is framed as being "granted" by "generous" organizations. One worker in our study went through multiple rounds of negotiating with her employer for dignified part-time work only to have it be granted then pushed back toward 50-60 hours each time before she "chose" to give up paid employment (Rothausen et al., in press). Qualitative research has made visible that a central cause of this phenomenon was-and is - in fact a lack of choice over hours worked, together with pay rates for part-time work, and that this disproportionately impacts mothers (Williams, 2000). 
With this and countless other phenomenon, even where the literature is "mature," as was the turnover literature into which my colleagues and I waded with our qualitative research study, workers' motivations are embedded not only in specific organizational constraints and relationships but also in their larger lives and social identities. Thus, deeper motivations at work engage identities as workers, spouses, parents, and community members as well as underlying global identities (Ladge, Clair, \& Greenberg, 2012; Rothausen et al., in press) and meanings of work in larger lives (Budd, 2011). Qualitative methods are well suited to better understanding these elements, which are often overlooked in quantitative work. Qualitative research thus helps us expand our theories while also surfacing the compelling stories that can have more impact, as the authors of the focal article point out.

In addition, qualitative methods are a good bridge to research on aspirational visions of what work could or should be. Many disciplines with which we could be in dialogue have different and valuable perspectives on work and organizations (Budd, 2011). Interdisciplinary work would allow us to generate important research questions and guide our research choices more intentionally, perhaps away from "Big B" research toward new, progressive forms of working, leading, and organizing that are so badly needed now.

Academics and other writers inside and outside IOP/OB/HR/IR call for a change in how business functions and focuses, away from economicsprimary, transactional values and objectives and toward prosocial, balanced values and objectives that encompass sustainability as well as dignity, meaning, and purpose in work and leadership (e.g., Avolio, 2010; Goodpaster, 2011; Khurana, 2007; Lefkowitz, 2016; Metcalf \& Benn, 2012). Several causal factors for the urgency of this need are invoked, including increasing global connection, interdependent local and global financial crises, growth in marginalized secondary labor markets, and profound environmental crisis. I argue that an interdisciplinary approach, combining evidence from social sciences research about "what is" in organizations with evidence from other fields such as arts and humanities disciplines about "what should be," is more likely to bear fruit for these purposes.

For example, a criticism of our field is making invisible, but taking as foundational, a preference for "economic and business values of an idealized free-market capitalism" over "a humanistic, moral vision" (Lefkowitz, 2016, pp. 141-142). An alternative model comes from business ethics, which has philosophy, theology, and other disciplinary foundations. Stakeholder theory explicates employees, consumers and customers, suppliers, and communities, along with shareholders and owners, as having a stake in employment policies and practices, with some interests being mutual and others divergent, although perhaps only divergent in the short term (Goodpaster, 2011). 
Taking this perspective seriously, alone, could open up countless research questions for IOP in new areas that could then be refined through the theorybuilding capabilities inherent in qualitative research.

This dialogue could occur with numerous disciplines. Examples of dialogue with philosophy and theology through business ethics include work involving the first author of the focal article (Michaelson, Pratt, Grant, \& Dunn, 2014) and myself (Rothausen, in press). The arts also offer rich opportunities for exploring other perspectives on work in organizations (e.g., Adler, 2015; Lindsey, 2011; Taylor \& Ladkin, 2009). If we as a field are not in dialogue with these related fields, we risk increasing irrelevance to the big questions of our era. This interdisciplinary work often needs further empirical exploration (mine does) yet is not conducive to the reduction to variables that is necessary for quantitative methods.

In addition to reasons outlined by the authors of the focal article, then, qualitative methods are especially well suited for inquiries into the deep, complex, and socially embedded human motivations related to work and for inquiries into deep exploration of what could or should be in the world of work, in part through inter- and cross-disciplinary inquiry. Along with others, I argue that it is just such inquiries that are most needed now in IOP and related fields.

\section{References}

Adler, N. J. (2015). Finding beauty in a fractured world: Art inspires leaders-Leaders change the world. Academy of Management Review, 40, 480-494.

Avolio, B. J. (2010). Pursuing authentic leadership development. In N. Nohria \& R. Khurana (Eds.), Handbook of leadership theory and practice (pp. 739-768). Boston, MA: Harvard Business Press.

Budd, J. W. (2011). The thought of work. Ithaca, NY: Cornell University Press.

Creswell, J. W. (2007). Qualitative inquiry and research design. Thousand Oaks, CA: Sage.

Goodpaster, K. E. (2011). Goods that are truly good and services that truly serve: Reflections on "Caritas in veritate." Journal of Business Ethics, 100, 9-16.

Gregory, A., \& Miller, S. (2009). Work-life balance: A matter of choice? Gender, Work, and Organizations, 16, 1-13.

Khurana, R. (2007). From higher aims to hired hands. Princeton, NJ: Princeton University Press.

Ladge, J. J., Clair, J. A., \& Greenberg, D. (2012). Cross-domain identity transition during liminal periods: Constructing multiple selves as professional and mother during pregnancy. Academy of Management Journal, 55, 1449-1471.

Lefkowitz, J. (2016). News flash! Work psychology discovers workers! Industrial and Organizational Psychology: Perspectives on Science and Practice, 9(1), 137-144.

Lindsey, J. L. (2011). Fine art metaphors reveal leadership archetypes. Journal of Organizational and Leadership Studies, 18, 56-63.

Metcalf, L., \& Benn, S. (2012). The corporation is ailing social technology: Creating a "fit for purpose" design for sustainability. Journal of Business Ethics, 111, 195-210.

Michaelson, C., Pratt, M. G., Grant, A. M., \& Dunn, C. P. (2014). Meaningful work: Connecting business ethics and organizational studies. Journal of Business Ethics, 121, 77-90.

Pratt, M. G., \& Bonaccio, S. (2016). Qualitative research in I-O psychology: Maps, myths, and moving forward. Industrial and Organizational Psychology: Perspectives on Science and Practice, 9(4), $693-715$. 
Rothausen, T. J. (2016). Organizational dependent care support. In T. D. Allen \& L. T. Eby (Eds.), The Oxford handbook of work and family (pp. 271-285). New York, NY: Oxford University Press.

Rothausen, T. J. (in press). Integrating leadership development with Ignatian spirituality: A model for designing a spiritual leader development practice. Journal of Business Ethics.

Rothausen, T. J., Henderson, K. E., Arnold, J. K., \& Malshe, A. (in press). Should I stay or should I go? Identity and well-being in sensemaking about retention and turnover. Journal of Management.

Taylor, S. S., \& Ladkin, D. (2009). Understanding arts-based methods in managerial education. Academy of Management Learning and Education, 8, 55-69.

Weiss, H. M., \& Rupp, D. E. (2011). Experiencing work: An essay on a person-centric work psychology. Industrial and Organizational Psychology: Perspectives on Science and Practice, 4(1), 83-97.

Williams, J. (2000). Unbending gender: Why work and family conflict and what to do about it. New York, NY: Oxford University Press.

\section{Taking Qualitative Methods a Step Further to Team Science}

Lorena Solis, Theresa Aristomene, Jennifer Feitosa, and Ebony Smith The City University of New York, Brooklyn College

Pratt and Bonaccio's (2016) focal article properly reviews and identifies the need for qualitative research methods in our field. However, they overlooked one important benefit-team science-that is crucial to current organizations. Despite the fact that qualitative research in team science is lacking, we suggest that with qualitative research we can gain more insight into what teams need in order to be effective. According to Kozlowski and Bell (2003), team dynamics are historically looked at in a static way in teams research, solely focusing on individuals' perceptions of the team at a given time as opposed to multilevels over time. In an attempt to further expand on how qualitative research can examine constructs that purely quantitative methods may not, the purpose of this commentary is to highlight importance of qualitative research regarding its ability to capture team dynamics as they occur in the real world. The need for qualitative methods exists across various components (i.e., inputs, team emergent states, processes, outputs) when it comes to teams. We argue that how these components appear, happen, and, more importantly, evolve over time should be taken into consideration. The current commentary highlights how qualitative research can start to fill the gap of understanding team dynamics and how to improve team practices by taking time into consideration.

Lorena Solis, Theresa Aristomene, Jennifer Feitosa, and Ebony Smith, Department of Psychology, The City University of New York, Brooklyn College.

Correspondence concerning this article should be addressed to Jennifer Feitosa, Department of Psychology, RM 4111D, The City University of New York, Brooklyn College, 5401 James Hall, 2900 Bedford Avenue, Brooklyn, NY 11210. E-mail: jennifer.feitosa81@brooklyn.cuny.edu 